\title{
Study the effect of eluent composition on benzimidazole and its derivatives retention on hypercrosslinked polystyrene
}

\author{
(C) Anastasia A. Yadrova, Roman V. Shafigulin, and Andzhela V. Bulanova \\ Department of «Physical Chemistry and Chromatography» of the Samara University. \\ Moskovskoye shosse St., 34. Samara, 443086. Russia. \\ Phone:+7 (846) 334-54-47.E-mail:yadrovaaa@mail.ru
}

\begin{abstract}
*Supervising author; ${ }^{+}$Corresponding author Keywords: benzimidazole, high performance liquid chromatography (HPLC), Snyder-Sochisnky model, supercrosslinked polystyrene, adsorption.
\end{abstract}

\begin{abstract}
The effect of water-acetonitrile and water-methanol eluents composition on newly synthesized benzimidazole derivatives sorption by supercrosslinked polystyrene (SCP) using high performance liquid chromatography was studied. It is shown that the nature of the organic modifier affects on the considered biologically active compounds sorption. The angular coefficients of the Snyder-Sochevinsky equation, characterizing the number of organic modifier molecules, displaced by one molecule of sorbate, for benzimidazole derivatives, are calculated. The angular coefficients was calculated from the dependence, characterized by a high coefficient of determination. The article demonstrated that the Snyder-Sochevinsky model could be used for describing of all studied compounds sorption in the system "SCP - water-methanol eluent" and for describing of volume sorbates with hydrophobic substituting groups sorption in the system "SCP - water-acetonitrile solution". The value of the slope of the Snyder-Sochevinsky equation of benzimidazoles sorption from water-methanol solutions is higher than that from water-acetonitrile solution; this fact indicates a lower elution power of the water-methanol eluent in compare to water-acetonitrile eluent. The Snyder-Sochevinsky model is not fulfilled in the concentration range from $75 \%$ to $85 \%$ of acetonitrile for small volume benzimidazole molecules containing hydrophilic amino and hydroxymethylene groups in the «SCP - water-acetonitrile eluent» system.

The composition of the mobile phase influence of benzimidazoles sorption was studied. It is demonstraited the relationships between volume fraction of the organic modifier increase and decreases of benzimidazoles sorption.
\end{abstract}

\section{References}

[1] R.V. Shafigulin, A.V. Konstantinov, A.V. Bulanova, M.M. Il'in, V.A. Davankov. Phenylamide adamantane derivatives sorption on hypercrosslinked polystyrene from water-acetonitrile eluents. Russian Journal of Physical Chemistry A. 2016. Vol.90. No.11. P.1729-1733. (russian)

[2] I.N. Karaseva, M.O. Karasev, S.V. Kurbatova. Influence of the topology of molecules on the sorption of derivatives of 1,2,4-triazole and 1,2,4-triazine by nonpolar sorbents under conditions of liquid chromatography. Sorption and chromatographic processes. 2018. Vol.18. No.6. P.891-902. (russian)

[3] M.G. Shashidhar, P. Giridharb, B. Manohar. Kinetics and thermodynamics in downstream processing of medicinal fungi C. sinensis CS1197. Biochemical Engineering Journal. 2017. Vol.121. P.88-93.

[4] I.B. Dmitrieva, S.E. Erdny-Garyaev, A.S. Chukhno, E.Yu. Pavlova, M.O. Koryakovskaya, and A.A. Pyurbeeva. Adsorption of sodium diclofenac on activated carbon, oxide and iron(III) hydroxide. Butlerov Communications. 2018. Vol.53. No.3. P.136-141. DOI: 10.37952/ROI-jbc-01/18-53-3-136

[5] O.A. Golovanova, and K.K. Golovchenko. Study of the surface properties of brushite during sorption of amino acids. Butlerov Communications. 2017. Vol.50. No.6. P.77-85. DOI: 10.37952/ROI-jbc-01/17-506-77

[6] V.D. Shatc, O.V. Sahartova. High Performance Liquid Chromatography: Fundamental theories. Methodology. Application in medicinal chemistry. Riga: Zinatne. 1988. 390p.

[7] Fa Zhou, Ruilin Man, and Jianhan Huang Alkoxy Modified Hyper-Cross-Linked Polymers with Hierarchical Porosity and Their Adsorption of Salicylic Acid from Aqueous Solution Ind. Eng. Chem. Res. 2018. Vol.57. No.37. P.12420-12428. 
[8] V.V. Tolmacheva, D.I. Yarykina, O.N. Serdiuk, V.V. Apyari, S.G. Dmitrienko, Yu.A. Zolotov. Adsorption of catecholamines from their aqueous solutions on hypercrosslinked polystyrene. Reactive and Functional Polymers. 2018. Vol.131. P.56-63.

[9] Xiao Ling a, Hebing Li b, Hongwei Zha b, Chunlian He a, $\Uparrow$, Jianhan Huang Polar-modified post-crosslinked polystyrene and its adsorption towards salicylic acid from aqueous solution. Chemical Engineering Journal. 2016. Vol.286. P.400-407.

[10] N.A. Nekrasova, S.V. Kurbatova, M.N. Zemcova. Tetrahydroquinoline derivatives retention on hypercrosslinked polystyrene under conditions of liquid chromatography from weakly polar eluents. Sorption and Chromatographic Processes. 2018. Vol.56. No.11. P.25-31. (russian)

[11] V.A. Davankov, K.S. Sychev, M.M. Il'in. Application of hypercrosslinked polystyrene sorbents in high performance liquid chromatography. Industrial Laboratory. 2003. Vol.69. No.4. P.3-7. (russian)

[12] A.A. Yadrova, V.S. Pisareva, R.V. Shafigulin, A.V. Bulanova. Study of thermodynamic of certain benzimidazole derivatives sorption from water - methanol solutions on hexadecyl silica gel. Sorption and Chromatographic Processes. 2018. Vol.18. No.4. P.515-526. (russian)

[13] S.A. Dzhabieva, D.B. Tagiev, N.A. Zeinalov, and S.V. Kurbatova. Thermodynamics of benzotriazole derivatives sorption from water-organic eluents. Butlerov Communications. 2018. Vol.56. No.12. P.1-9. DOI: 10.37952/ROI-jbc-01/18-56-12-1

[14] I.N. Karaseva, E.I. Demchenko, and S.V. Kurbatova. 1,2,4-Triazine and 1,2,4-triazole derivatives sorption under condition of high performance liquid chromatography. Butlerov Communications. 2018. Vol.54. No.5. P.40-49. DOI: 10.37952/ROI-jbc-01/18-54-5-40

[15] A.S. Morozov, M.N. Kopitsyna, I.V. Bessonov, N.V. Karelina, A.V. Nuzhdina, I.Y. Sarkisov, L.A. Pavlova, M.P. Tsyurupa, Z.K. Blinnikova, V.A. Davankov. A selective sorbent for removing bacterial endotoxins from blood. Russian Journal of Physical Chemistry A. 2016. Vol.90. No.12. P.1876-1882. (russian) 